IJAMSR 3 (7) www.ijamsr.com CrossRef: https://doi.org/10.31426/ijamsr.2020.3.7.3511

\title{
THE STUDY OF FOREIGN DIRECT INVESTMENT IN INDIA
}

\section{Gnanadeva. S}

Asst. Professor of Economics, Govt. First Grade College, Chikkanayakana Halli, Karnataka, India

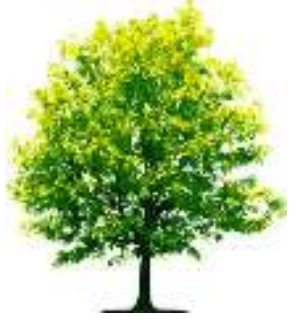

Keywords:

Foreign Direct

Investment, India, economic development, foreign companies, Indian businesses

\section{A B S T RA C T}

Foreign direct investment (FDI) in India is a major monetary source for economic development in India. Foreign companies directly invest in rapidly expanding Indian private enterprises to benefit India from cheaper salaries and changing business environments. Economic freedom started in India, and since then, in India, FDI has steadily grown, creating over one crore (10 million) in jobs in the future. On 17 April 2020, the Department of Promotion of Industry and Internal Trade announced that India had revised its strategy for FDI to shield Indian companies from "opportunistic takeovers of Indian companies by virtue of the new COVID-19 pandemic." Although the new FDI Policy does not restrict markets, the Policy ensures that the Ministry of Commerce and Industry now scrutinizes all FDIs. In 2019, worldwide FDI flows 1 grew 12 percent to USD 1,426 billion compared to 2018. However, flows remained extremely low in 2019, which accounted for only 1.6 percent of GDP from 2015 to 2017 compared with more than 2 percent since the 2018 FDI reform was very low. FDI flows were lower in 2018 and 2019, as flows fell in the aftermath of the 2008 global financial crisis, than they did at any time since 2010. This newsletter focuses mainly on FDI status in 2019 before many economies began to suffer from the COVID-19 virus. Section 4 and a separate notice on COVID-19 impact on FDI flows provide further information on current FDI flows and projections by the end of 2021

Citation: Gnanadeva. S (2020). The Study Of Foreign Direct Investment In India. International Journal of Advanced Multidisciplinary Scientific Research (IJAMSR) ISSN:2581-4281, 3 (7), July 2020, Pp 1 - 13 
IJAMSR 3 (7) www.ijamsr.com CrossRef: https://doi.org/10.31426/ijamsr.2020.3.7.3511

\section{Introduction}

Foreign Direct Investment (FDI) was a big non-debt financial aid for Indian economic development, apart from being the vital engine of economic growth. In order to make use of relatively low incomes, foreign companies invest in India, special investment privileges such as tax exemptions, etc. It also means achieving technical know-how and job creation in a country where foreign investment is made. The favorable policy regime of the Indian Government and the robust business environment ensure the continued flow of foreign capital into the country. In recent years the government has taken many initiatives, including relaxing FDI standards in sectors such as defence, refineries of PSU oil, telecommunications, electricity exchanges and stock exchanges. The FDI equity influx in India amounted to US\$ 469.99 billion in April 2000 and March 2020, the Department of Industry Promotion and Internal Trade, which states that the efforts made by government to improve business ease and the relaxation of FDI standards yield results.
Equity inflow to India in 2019-20 amounted to US\$ 49.97 billion. The 2019-20 data show that the highest inflow of US\$ 7.85 billion in service equity, computer and hardware in US\$ 7.67 billion, telecommunications in US\$ 4.44 billion, and US\$ 4.57 billion in trade has been reported in the services sector. Data for the 2019-20 financial years the maximal inflow of FDI's equity in Singapore (14.67 billion USD) during 2019-20 has been received by India, followed by Mauritius ( 8.24 billion USD), the Netherlands (6.50 billion USD), the US (4.22 billion USD) and Japan (3.22 billion USD).

In order to limit the spread of the COVID-19 pandemic, several governments have taken strict public health measures. These measures on public health led to severe economic disturbances, which affected the decisions of firms on foreign direct investment (FDI). In order to avoid, or buffer, the economic effects of the public health crisis, the governments have also taken substantial economic policies. The impact that these public health and economic policy responses will have on FDI flows depends on the success. In the postpandemic economic recovery, FDI could play an important role in supporting economies. 
IJAMSR 3 (7) www.ijamsr.com CrossRef: https://doi.org/10.31426/ijamsr.2020.3.7.3511

Evidence of past crises has shown that, thanks to its relationships and access to financial resources of its parent businesses, foreign affiliates, including small and medium-sized enterprises, can demonstrate greater resilience during crises. For emerging and developing economies, FDI could have been especially important given that these economies were fled other sources of international funding, including portfolio investment. Sadly, it appears that the pandemic has a particularly severe effect on FDI flows to such economies. The primary and manufacturing sectors, for example, that make up a greater share of FDI in many of these countries than in most developed economies, have been especially hard hit by the pandemic (see the upcoming OECD report on public-health and development finance impacts of COVID-19).

* FDI flows are projected to decline over 30\%, even in the most optimistic public health scenario in 2020, and government economic support policies to tackle the COVID-19 pandemic and its consequent recession.

* FDI flows to developing countries are expected to decrease further as a large part of their FDI is accounted of by sectors which have been seriously affected by the pandemic, including the main and manufacturing industries.

* During and after the crisis FDI may play an important role to aid economies, helping governments to tackle the pandemic and liaison with local businesses by helping their affiliates financially.

* FDI flows have steadily declined over the past five years, and they could remain below pre-crisis levels throughout 2021 if the public health measures and economic support policies are not effective. 
IJAMSR 3 (7) www.ijamsr.com CrossRef: https://doi.org/10.31426/ijamsr.2020.3.7.3511

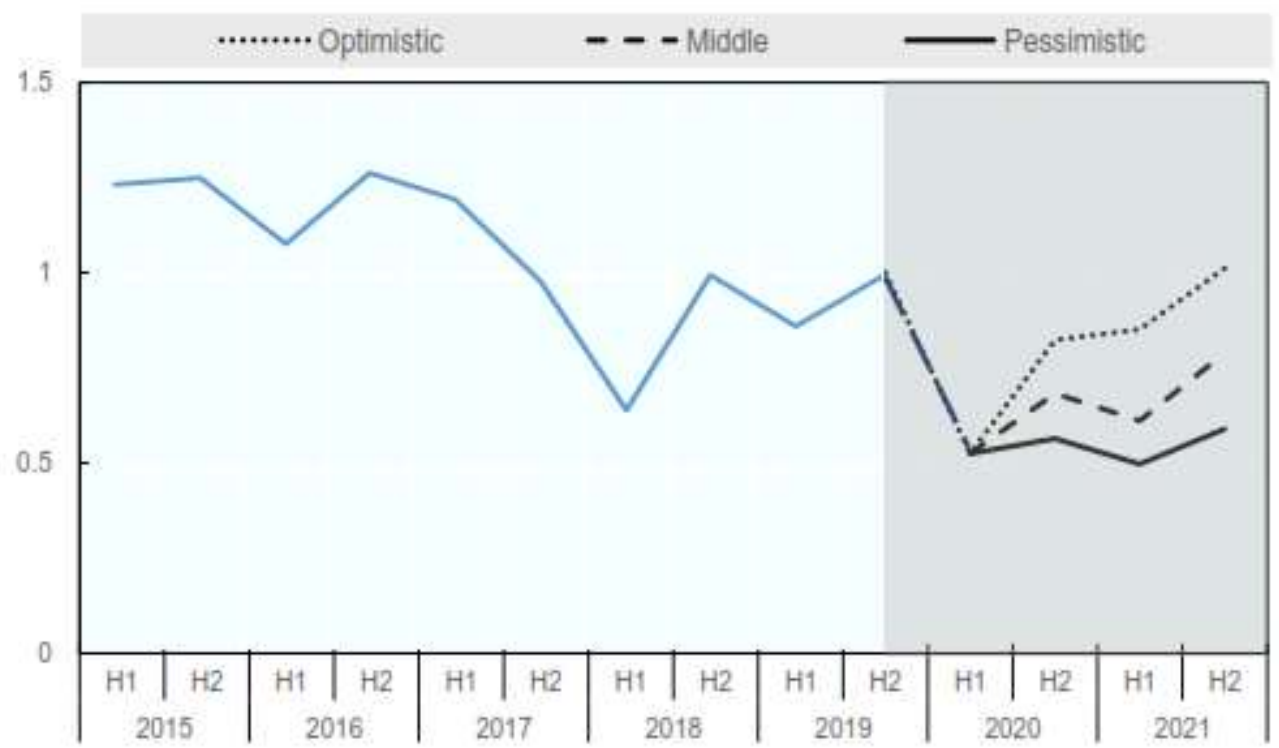

Figure 1. FDI Flows under Different Scenarios on the Effectiveness of Public Health and Economic Policy Measure

The OECD estimates show that FDI flows are projected to plunge by at least 30 percent in 2020 compared with 2019 before returning to pre-crisis rates by the end of 2021 , even under the most optimistic scenario. The six-month patterns from 2015 until 2019 and potential scenarios are illustrated in Figure 1 on a halfyear basis up to 2021. It indicates that the flows of FDI in the first half of 2020 are projected to drop sharply. The effect on FDI flows will then rely on the effectiveness of government policies on public health and economic policy. The fall in FDI flows continues longer under the negative scenario.

\section{Investments/ Developments}

Some of the significant FDI announcements made recently are as follows:

- Between April 23 and July 16, 2020, Jio Platforms Ltd. sold 25.24 per cent stake worth Rs 1.52 trillion (US\$ 21.57 billion) to various global investors from separate deals involving Facebook, Silver Lake, Vista, General Atlantic, Mubadala, Abu Dhabi Investment Authority (ADIA), TPG Capital, L. Catterton, Public Investment Fund (PIF), Intel Capital, Qualcomm Ventures and Google. This is the largest continuous fundraise by any company in the world. 
IJAMSR 3 (7) www.ijamsr.com CrossRef: https://doi.org/10.31426/ijamsr.2020.3.7.3511

- In May 2020, Philips, Dutch health tech and consumer electronics company, announced its plan to invest Rs 250-300 crore (US\$ 35.47-42.56 million) to boost its manufacturing and $\mathrm{R} \& \mathrm{D}$ facilities in India.

- In January 2020, Amazon India announced investment of US\$ 1 billion for digitising small and medium businesses and creating one million jobs by 2025 .

- In January 2020, MasterCard announced its plans to invest up to US\$ 1 billion in India over the next five years to double its research and development effort in the Indian market.

- In October 2019, French oil and gas giant, Total S.A., acquired 37.4 per cent stake in Adani Gas Ltd for Rs 5,662 crore (US\$ 810 million), making it the largest FDI in India's city gas distribution (CGD) sector.

- In August 2019, Reliance Industries (RIL) announced one of India's biggest FDI deals with Saudi Aramco to buy a 20 per cent stake in Reliance's oil-to-chemicals (OTC) business at an enterprise value of US\$ 75 billion.

\section{Government Initiatives}

In May 2020, Government increased FDI in Defence manufacturing under the automatic route from 49 per cent to 74 per cent.

In April 2020, Government amended existing consolidated FDI policy for restricting opportunistic takeovers or acquisition of Indian companies from neighboring nations.

In March 2020, Government permitted nonresident Indians (NRIs) to acquire up to 100 per cent stake in Air India.

In December 2019, Government permitted 26 per cent FDI in digital sectors.

In August 2019, Government permitted 100 per cent FDI under the automatic route in coal mining for open sale (as well as in developing allied infrastructure like washeries).

In Union Budget 2019-20, the Government of India proposed opening FDI in aviation, media (animation, AVGC) and insurance sectors in consultation with all stakeholders. 
IJAMSR 3 (7) www.ijamsr.com CrossRef: https://doi.org/10.31426/ijamsr.2020.3.7.3511

100 per cent FDI is permitted in insurance intermediaries.

The Government of India had been preparing a road map by February 2019 to achieve the USD 100 billion FDI influx goal.

The government of India published in February 2019 a draft e-commerce national policy intended to promote FDI on the e-commerce marketplace model. In addition, it claimed that the FDI e-commerce policy had been designed to provide all participants with a level playing field.

Through the Indian insurance intermediaries, the Government of India had intended to take into account 100 per cent FDI to promote and raise more funds.

In December 2018, FDI e-commerce laws were updated by the Indian Government. According to the revised regulations, the market-based ecommerce model provided for 100 percent FDI. Sales by any seller by an e-commerce marketplace company or its group companies were also limited to $25 \%$ of the revenue of that seller in total.

\section{Coronavirus Pandemic Impact}

On 18 April 2020, the Indian Government issued an order that protects Indian businesses against FDI during the pandemic. All countries that share an Indian land borders would now be examined before any FDI by the Ministry of Commerce and Industry. In terms of volume and value, India is the 3rd largest pharmaceutical market. The Indian pharmaceutical industry will expand at a compound annual growth rate of 20 percent between 2015 and 2020. In this sector, 74\% FDI is allowed.

\section{FDI in First Half Of 2020}

As a result of the pandemic and the resultant supply disturbances, demand contractions and economic actors' pessimistic outlook, FDI is expected to drop sharply. The fall in FDI flows in the past five years is accentuated and accelerated (Figure 2). Investing capital flows will also have an immediate effect on FDI flows as fuse and acquisition (M\&A) and Greenfield acquisitions are stopped, while. Equity capital flows will also be affected as companies retain. 
IJAMSR 3 (7) www.ijamsr.com CrossRef: https://doi.org/10.31426/ijamsr.2020.3.7.3511
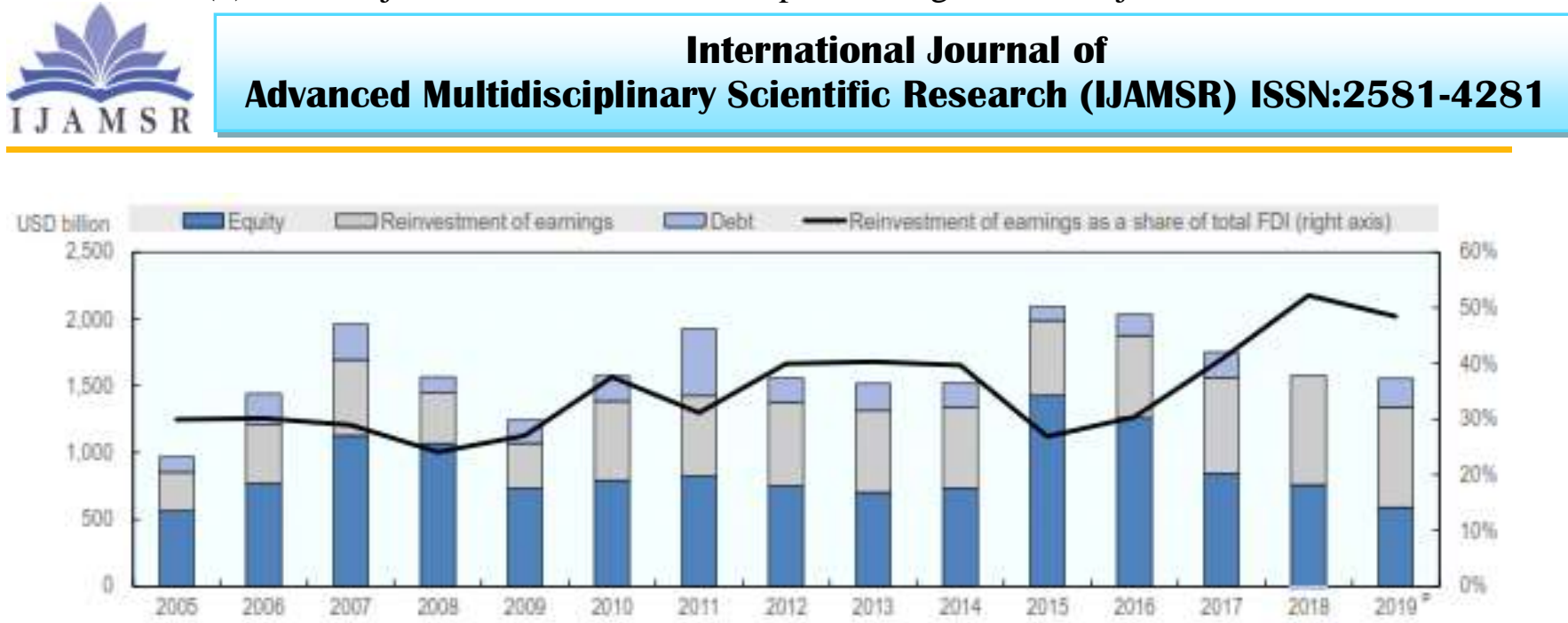

Figure 2. FDI flows by component, 2005 to 2019

Reinvested income has become a component of FDI flows which are increasingly important and account for over half of FDI influxes in 2019. The amount of returns reinvested is determined by two factors: earnings from direct investment firms, and the share reinvested by the direct investor.

Figure 3 shows the share of FDI profits in OECD countries reinvested between 2005 and 2019. The share of returns reinvested has shown a growing increase since 2013. The share of revenues reinvested fell by about half in the period following the financial crisis, from $45 \%$ in 2007 to $24 \%$ in 2008. Some companies have a normal, constant sum of income, and others have paid a higher share of income to other parts of the MNE. The share of earnings which are reinvested in the first half of 2020 is therefore expected to decrease.

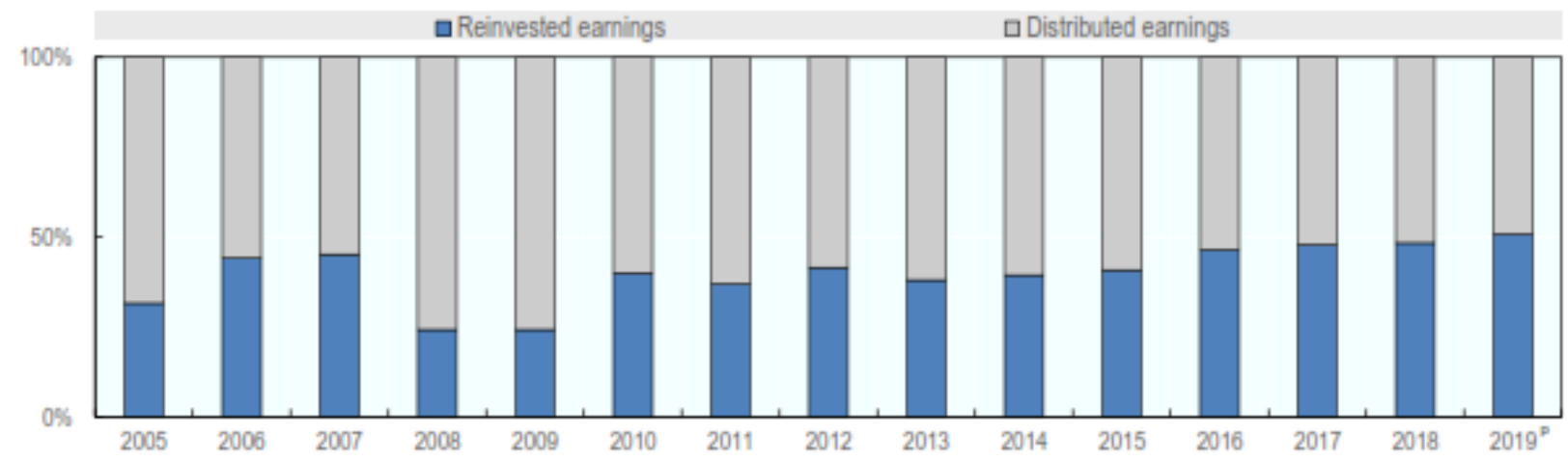

Figure 3. Share of earnings that are reinvested 
IJAMSR 3 (7) www.ijamsr.com CrossRef: https://doi.org/10.31426/ijamsr.2020.3.7.3511

The recent data from the refinitive report on cross-border M\&As show a substantial fall in completed transactions over the first quarter of 2020 (figure 4), but a spike in withdrawn deals is not shown. Instead, pending deals have increased. This means that direct investors have not so far tried to reverse their deal, but have seemed to be stopping them, mainly because of the difficulty of valuation in the present situation. Sinine companies will probably wait until economic developments take such a step in the near future as it is difficult and potentially expensive for them to withdraw deals. In the short term, capital flows will decrease because of too many deals, but they can mean a future rise when such transactions are completed with the stabilization of the economy. In the absence of a recovery in the economy, however, firms that begin to abandon their businesses, maybe citing clauses which allow target companies to continue their routine business activities before the deal is closed. In developed economies with more than three quarter of completed cross-border $\mathrm{M} \& \mathrm{~A}$, cross-border $\mathrm{M} \& \mathrm{~A}$ is a especially significant factor. Greenfield investments, on the other hand in emerging and developing economies, tend to play a greater role in FDI.

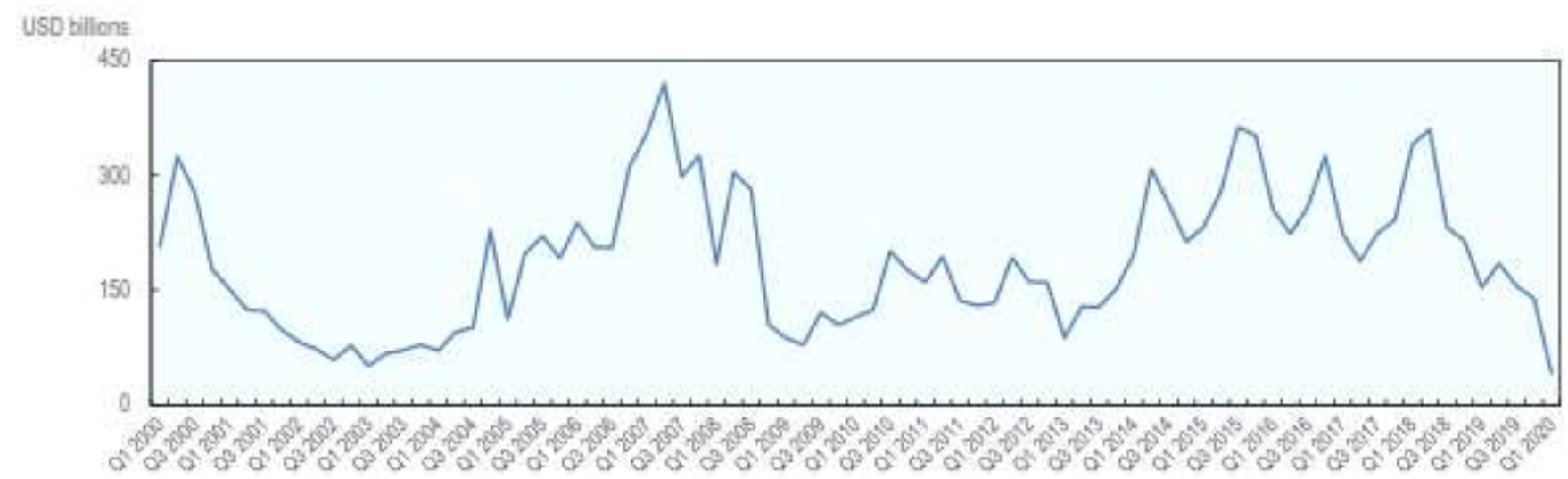

Figure 4. Completed cross-border M\&A deals in advanced economies, 2000-2020 
IJAMSR 3 (7) www.ijamsr.com CrossRef: https://doi.org/10.31426/ijamsr.2020.3.7.3511

The latest Greenfield FDI data from the FDI Markets database from the Financial Times further show that investors are increasingly reluctant to explore new opportunities for investment in the face of the pandemic. This is evidenced by the decrease in new project launches compared with previous years in the first two months of 2020 (Figure 5). The value of greenfield FSP promises fell by more than

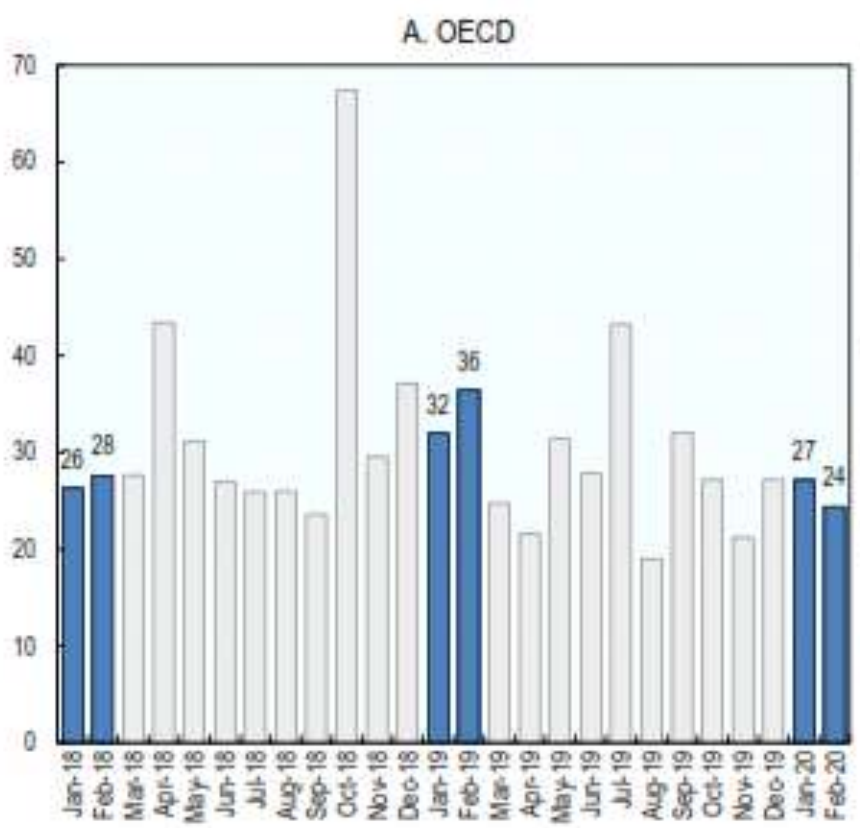

$36 \%$ compared with 2019 and 15 to30\% compared to 2018 in non-OECD economies. This decrease is more pronounced. In January 2020, the announced investments in nonOECD economies were marginally less than in February.

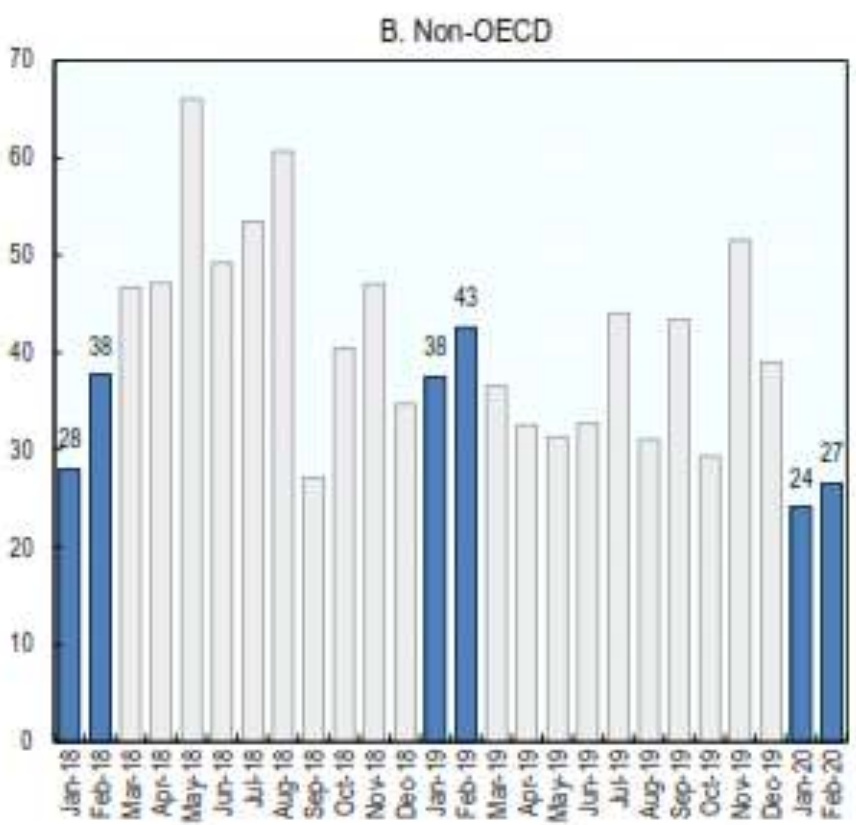

Figure 5. Value of announced Greenfield projects, 2018-2020

Divestments could also have an impact on FDI flows

Disposition is typically a regular and normal part of global supply chains, allowing businesses to adapt their activities to alter market circumstances rapidly. Out of every 5 international companies was allocated every 5 years by an OECD survey. An OECD report found that A global survey showed before the outbreak that 84 percent of the companies 
IJAMSR 3 (7) www.ijamsr.com CrossRef: https://doi.org/10.31426/ijamsr.2020.3.7.3511

surveyed expected to conduct such operations in 2020-21. Understanding the dynamics of divestment is critical , especially as divestments can impact the output of affected companies and the well-being of employees and their communities. Even more serious effects on jobs and production in effective communities would, for example, occur, if formerly foreign companies that were sold out to their global parent, on average about 25 percent decrease in sales and values as well as 15 per cent in employment.

\section{FDI flows through the end of 2021}

The effect on flows will differ significantly in the medium term (seventh half of 2020 and 2021) depending on the performance of public health policies and economic policies. The optimist scenario is that income is projected to begin increasing by the end of 2021, when the economy improves, in the second half of 2020 and that the share reinvested by direct investors will also be restored to historic levels. Nearly all the previously reported M\&A deals pending and the Greenfield developments revealed would be completed. Although the lack of new investment negotiations could lead to a medium-term decline, new investments return to normal at the end of 2021 . Historical rates of departments will remain. Consequently, FDI flows are expected to drop from 30 per cent to $40 \%$ in 2020 before they will return to precrisis levels by similar amounts in 2021. As already mentioned, it is important to note that the flows in FDI have decreased since 2015, and the flows in FDI have been lower since 2018 and 2019 than in any other year.

Under the middle scenario, the economic recovery will be uneven. While the income will recover in some sectors, others will remain below pre-crisis levels; the share of income reinvested will recover slightly but not historically in all industries. The pending M\&A transactions and planned developments in Greenfield will be completed, but further investments will be abandoned. In addition to the lack of newly negotiated projects during this time, capital flows are being reduced by the continued decline in new transactions. Nonetheless, other foreign acquisitions may take place when stronger financial firms buy properties at competitive rates. Divestments by financially troubled firms would also reduce equity capital flows. Selling existing companies, but even liquidation will require these divestments. In total FDI flows will decline by 35 to $45 \%$ in 2020 , but would 
IJAMSR 3 (7) www.ijamsr.com CrossRef: https://doi.org/10.31426/ijamsr.2020.3.7.3511

remain around a third below their pre-crisis rate until recovery in 2021.

\section{Under the pessimistic scenario, earnings} remain depressed in most sectors and so does the share of earnings reinvested. Capital flows are substantially decreased as many M\&A transactions pending and Greenfield developments have been announced to be scrapped, as they are no longer of strategic value or the investor faces financial constraints and less investments in Greenfield are completed. There would have been declining new M\&As and greenfield investments. Divestments by fighting companies, including more liquidation, would be more common. FDI flows in general will decrease by more than $40 \%$ by 2020 and will continue to decline flat until 2021 if a vaccine launch enables recovery to begin.

\section{CONCLUSION}

In India the Foreign direct investment (FDI) has received a staged improvement from instigate of the Make in India scheme, according to recent survey. In particular for manufacturing from 2019 to 2020, flows from FDIs (40 percent) have increased unbelievably. India is ranked 14th in the world's manufacturing production. This study highlights the government's recent efforts to promote and advance the FDI in diverse sectors. Foreign direct investment in the various sectors of the economy has developed tremendously in India. Although the Indian Government has developed a way to attract FDI in different fields, this paper focuses on explaining the impact of make on FDI in India. The competitive investment environment in India has generated the influx of FDI to India and the competitive environment provides the foundation for the enterprise and development of FDI. Different main policy initiatives are required to boost the Indian infrastructure and to increase the internal absorption potential. To enrich local businesses, to improve macroeconomic conditions and to increase process of development, the FDI will be the best inflows and to promote economic growth. 
IJAMSR 3 (7) www.ijamsr.com CrossRef: https://doi.org/10.31426/ijamsr.2020.3.7.3511

\section{References}

1) Borga, M.,P. Ibarlucea FloresandM. Sztajerowska (2020), "Drivers of divestment decisions of multinational enterprises -A cross-country firm-level perspective", OECD Working Papers on International Investment, No. 2019/03,

2) Cadestin, C., et al. (2018), "Multinational enterprises and global value chains: New Insights on the trade-investment nexus", OECD Science, Technology and Industry Working Papers, No. 2018/05, OECD Publishing,

Paris, https://doi.org/10.1787/194ddb63-en.

3) Celik, S., G. Dimertas, and M. Isaksson (2020), Corporate Bond Market Trends, Emerging Risks, and Monetary Policy,OECD Capital Market Series, Paris, https://www.oecd.org/corporate/corporatebond-market-trends-emerging-risks-andmonetary-policy.htm.

4) Cohen, M. A. and H. L. Lee (2020), "Designing the Right Global Supply Chain Network", Manufacturing \& Service Operations Management, Vol. 22, No. 1

5) CNBC (2020), "GM offers manufacturing blueprints for face masks to 600 auto parts suppliers amid virus pandemic"
6) De Backer, K. and D. Flaig (2017), "The future of global value chains: Business as usual or "a new normal"?", OECD Science, Technology and Industry Policy Papers, No. 41, OECD Publishing

7) Ernst \& Young (2019), Global Corporate Divestment Survey, www.ey.com/en_gl/divestment-study

8) Forbes (2020), “General Motors Embraces Supply Chain Resiliency”, www.forbes.com/sites/stevebanker/2016/05 /31/general-motors-embraces-supplychain-resiliency/\#38d054b13684

9) Fortune (2020), “Europe's auto factories are closing. Experts fear a lost decade is coming",

www.fortune.com/2020/03/17/coronavirusimpact-shutdown-european-auto-sectorvolkswagen

10) Javorcik, B. S. and S. Poelhekke (2017), "Former Foreign Affiliates: Cast Out and Outperformed?", Journal of the European Economic Association, Vol 15, Issue 3, 501-539.

11) Kose, A., N. Sugawara and M. E. Terrones (2020), "Global Recessions, "Policy Research Working Paper Series 9172, World Bank. 
International Journal of Advanced Multidisciplinary Scientific Research (IJAMSR) ISSN:2581-4281 Volume 3, Issue 7, July 2020

IJAMSR 3 (7) www.ijamsr.com CrossRef: https://doi.org/10.31426/ijamsr.2020.3.7.3511

12) McKinsey (2020), Scenarios for the Economic Impact of the COVID 19 Crisis.

13) OECD (2018), Multinational enterprises in the global economy: Heavily debated but hardly measured. Policy Note

14) Alfaro, L. (2019). "Gains from Foreign Direct Investment: Macro and Micro Approaches." The World Bank Economic Review, 30 (Supplement 1): S2-S15.

15) Alfaro, L., S. Kalemli-Ozcan and S. Sayek (2019). “Foreign Direct Investment, Pro ductivity and Financial Development: An Empirical Analysis of Complementarities and Channels". The World Economy32, 111-135

16) Dunning, Lundan (2018), Multinational Enterprises, 2nd Edition, Edward Elgar Publishing Limited, Pp. 2 -8.

17) Narayana (2019), Foreign Investment and Indian Economy (Ed), Manglam Publishers \& Distributors, Delhi, Pp. 26 - 27.

18) Singh, Gupta (2019), "Foreign Direct Investment and Industrial Development in India", Thesis submitted to Maharshi Dayanand University Rohtak for the degree of doctor of philosophy in Department of Commerce.
19) Lakshmana Rao, Ravikanth (2019), Make in India and Foreign Direct Investment (FDI) - synergetic effect on Economic Growth, SSRN Journal, Pp. 1-8.

20) Agarwal J., Khan M.A (2019)., "Impact of FDI on GDP: A comparative study of China and India", International Journal of Business Management, Vol. 6, Issue - 10, 2011, pp. 71-79.

21) Sharma, Khurana (2019), Role of FDI in Various Sectors, International Journal of Advances in Management and Economics, Vol. 4, Issue - 3, 2013, Pp. 12 - 14.

22) Mahendra Sinha, Arindam, Partha (2018), Foreign Direct Investment and Indian Industries: A Dynamic Panel Study, International Journal of Pure and Applied Mathematics, Volume 118 Issue. 18, 2018,ISSN: 1279-1294, Pp. 1279 - 81. 